\title{
The features of methane fluxes in the western and eastern Arctic A review. Part I
}

\author{
Renat B. Shakirov*1 \\ Susan Mau ${ }^{2}$ \\ Galina I. Mishukova**1 \\ Anatoly I. Obzhirov ${ }^{1}$ \\ Maria V. Shakirova ${ }^{3}$ \\ Olga V. Mishukova ${ }^{1}$
}

\author{
${ }^{1}$ IV.I.Il ichev Pacific Oceanological Institute, FEB RAS, Vladivostok, \\ Russia \\ ${ }^{2}$ University of Bremen, Bremen, Germany \\ ${ }^{3}$ Pacific Geographical Institute, FEB RAS, Vladivostok, Russia \\ *E-mail: ren@poi.dvo.ru \\ **E-mail:gmishukova@poi.dvo.ru
}

\section{Abstract Резюме Rus PDF}

The article provides a review of the modern researches on methane content and its emissions into the atmosphere in the Arctic region. We discussed various methane sources and summarized the certain existing data of its origins as well as driving forces of the methane upward and lateral migration. The greenhouse gas flux of methane from the Arctic marginal seas plays a significant climatic, geopolitical, and social role, but remains one of the most debated topics in ocean sciences.The Arctic seas are presented today in the literature both as a threat of a global ecological catastrophe due to methane emissions, and as sources of gigantic deposits of the fossil carbon, including coal, permafrost strata, oilgas and gas hydrates storages, rivers runoff, and as the most sensitive indicator of regular (evolutionary) processes of climate change. Large amounts of organic matter are stored in permafrost on land and under the sea that have been partly and further will be degraded to $\mathrm{CO}_{2}$ and $\mathrm{CH}_{4}$. Reviewed studies suggested that the Arctic is a substantial source of $\mathrm{CH}_{4}$ to the atmosphere (between 32 and $\left.112 \mathrm{Tg}\left(\mathrm{CH}_{4}\right) \mathrm{yr}^{-1}\right)$, primarily because of the large area of wetlands throughout the region. A recent assessment of the Arctic region identified thousands of gigatonnes $\left(1 \mathrm{Gt}=10^{15} \mathrm{~g}\right)$ of stored carbon, including unresearched deposits of methane, stored within permafrost and as gas hydrate. We concluded that methane sources and the pathways of its transportation in sediments and into the water column of the Arctic seas are characterized by the extreme ambiguity of existing estimates, due to the complexity of natural gas genesis and its migration mechanisms (diffusion, filtration, bubble gas fluxes). These differences illustrate that we currently cannot predict changes of the methane emissions from the Arctic, as too many unknowns and too large uncertainties persist. Although release of $\mathrm{CH}_{4}$ to the ocean and atmosphere has become a topic of discussion, the region remains sparingly explored. Submarine permafrost is still poorly studied, mainly due to the lack of direct observations. Objective assessment of the methane distribution and dynamics of its oxidation patterns in sediments and water column in the Arctic seas requires further studies based on the integrated marine expeditions, remote sensing and onland gas monitoring stations. Authors are experienced in methane flux and resources research in Arctic region since 1976th. The study is one of the important topic for planning of future research in the Arctic region, since Russian Federation will be in charge of International Arctic Council (a high level intergovernmental forum) for 2021-2023.

\section{Keywords}

methane, climate change, gas hydrate, permafrost, microbial methane turnover, microbial methane oxidation, seismo-tectonic pathways, methane emission, Arctic seas 
For citation: Shakirov R.B., Mau S., Mishukova G.I., Obzhirov A.I., Shakirova M.V., Mishukova O.V. The features of methane fluxes in the western and eastern Arctic: A review. Part I. Geosystems of Transition Zones, 2020, vol. 4, no. 1, p. 4-25. (In English, abstract in Russian). https://doi.org/10.30730/25418912.2020.4.1.004-025

Для цитирования: Шакиров Р.Б., Мау С., Мишукова Г.И., Обжиров А.И., Шакирова М.В., Мишукова О.В. Особенности потоков метана в западной и восточной Арктике: обзор. Часть I. Геосистемы переходных зон. 2020. Т. 4, № 1. С. 4-25. (На англ. языке, резюме на русском). https://doi.org/10.30730/2541-8912.2020.4.1.004-025

\section{References}

1. Angelis, de M.A., Lee C. 1994. Methane production during zooplankton grazing on marine phytoplankton. Limnology and Oceanography, 39(6): 1298-1308. https://doi.org/10.4319/10.1994.39.6.1298

2. ARA07C. 2017. Cruise Report 2016: Korea-Russia-Germany East-Siberian Sea Arc Project. Korea Polar Research Inst:: 108. URL: http://repository.kopri.re.kr/handle/201206/4995

3. Archer D., Buffett B., Brovkin V. 2009. Ocean methane hydrates as a slow tipping point in the global carbon cycle. Proceedings of the National Academy of Sciences, U.S.A, 106(49): 20596-20601. https://doi.org/10.1073/pnas.0800885105

4. Arrigo K.R., van Dijken G.L. 2015. Continued increases in Arctic Ocean primary production. Progress in Oceanography, 136: 60-70. https://doi.org/10.1016/j.pocean.2015.05.002

5. Astakhov A.S., Gusev E.A., Kolesnik A.N., Shakirov R.B. 2013. Conditions of the accumulation of organic matter and metals in the bottom sediments of the Chukchi Sea. Russian Geology and Geophysics, 54(9): 10561070. https://doi.org/10.1016/j.rgg.2013.07.019

6. Berchet A., Bousquet P., Pison I., Locatelli R., Chevallier F., Paris J.-D., Dlugokencky E.J., Laurila T., Hatakka J., Viisanen Y., Worthy D.E.J., Nisbet E., Fisher R., France J., Lowry D., Ivakhov V., Hermansen O. 2016. Atmospheric constraints on the methane emissions from the East Siberian Shelf. Atmospheric Chemistry and Physics, 16(6): 4147-4157. https://doi.org/10.5194/acp-16-4147-2016

7. Biastoch A., Treude T., Rüpke L.H., Riebesell U., Roth C., Burwicz E.B., Park W., Latif M., Böning C.W., Madec G., Wallmann K. 2011. Rising Arctic Ocean temperatures cause gas hydrate destabilization and ocean acidification. Geophysical Research Letters, 38(8): L08602. https://doi.org/10.1029/2011GL047222

8. Boetius A., Albrecht S., Bakker K., Bienhold C., Felden J., Fernández-Méndez M., Hendricks S., Katlein C., Lalande C., Krumpen T., Nicolaus M., Peeken I., Rabe B., Rogacheva A., Rybakova E., Somavilla R., Wenzhöfer F., Party R.P. et al. 2013. Export of algal biomass from the melting Arctic Sea ice. Science, 339(6126): 1430-1432. https://doi.org/10.1126/science.1231346

9. Bussmann I. 2013. Distribution of methane in the Lena Delta and Buor-Khaya Bay, Russia. Biogeosciences, 10: 4641-4652. https://doi.org/10.5194/bg-10-4641-2013

10. Bussmann I., Matousu A., Osudar R., Mau S. 2015. Assessment of the radio ${ }^{3} \mathrm{H}_{-} \mathrm{CH}_{4}$ tracer technique to measure aerobic methane oxidation in the water column. Limnology and Oceanography: Methods, 13(6): 312327. https://doi.org/10.1002/lom3.10027

11. Chand S., Knies J., Baranwal S., Jensen H., Klug M. 2014. Structural and stratigraphic controls on subsurface fluid flow at the Veslemoy High, SW Barents Sea. Marine and Petroleum Geology, 57: 494-508. https://doi.org/10.1016/j.marpetgeo.2014.06.004

12. Charkin A.N., Loeff, van der R.M., Shakhova N.E., Gustafsson Ö., Dudarev O.V., Cherepnev M.S., Salyuk A.N., Koshurnikov A.V., Spivak E.A., Gunar A.Y., Ruban A.S., Semiletov I.P. 2017. Discovery and characterization of submarine groundwater discharge in the Siberian Arctic seas: A case study in the BuorKhaya Gulf, Laptev Sea. The Cryosphere, 11: 2305-2327. https://doi.org/10.5194/tc-11-2305-2017

13. Chernykh D.V. 2014. Razrabotka metodov i programmnykh sredstv akusticheskogo zondirovaniia vodnoi tolshchi i dna okeana $v$ zonakh razgruzki metana [Development of methods and software for acoustic sounding of the water column and ocean floor in the zones of methane discharge]: extended abstract of cand. diss. in Engineering. Shirshov Inst. Oceanology of the RAS, Moscow. (In Russ.).

14. Collet T.S. 2014. International gas hydrate research. U.S. Geological Survey. 79 p. URL: http://energy.usgs.gov

15. Cramer B., Franke D. 2005. Indications for an active petroleum system in the Laptev Sea, north east Siberia. J. of Petroleum Geology, 28(4): 369-384. https://doi.org/10.1111/j.1747-5457.2005.tb00088.x

16. Damm E., Mackensen A., Budeus G., Faber E., Hanfland C. 2005. Pathways of methane in seawater: Plume spreading in an Arctic shelf environment (SW-Spitsbergen). Continental Shelf Research, 25(12-13): 14531472. https://doi.org/10.1016/j.csr.2005.03.003

17. Damm E., Helmke E., Thoms S., Schauer U., Noethig E., Bakker K., Kiene R. 2010. Methane production in aerobic oligotrophic surface water in the central Arctic Ocean. Biogeosciences, 7(3): 1099-1108.

https://doi.org/10.5194/bg-7-1099-2010 
18. Dlugokencky E.J., Bruhwiler L., White J.W.C., Emmons L.K., Novelli P.C., Montzka S.A., Masarie K.A., Lang P.M., Crotwell A.M., Miller J.B., Gatti L.V. 2009. Observational constraints on recent increases in the atmospheric $\mathrm{CH}_{4}$ burden. Geophysical Research Letters, 36: L18803, 5p. https://doi.org/10.1029/2009g1039780

19. Elliott S., Maltrud M., Reagan M., Moridis G., Cameron-Smith P. 2011. Marine methane cycle simulations for the period of early global warming. J. of Geophysical Research: Biogeosciences, 116(G1): G01010, 13 p. https://doi.org/10.1029/2010jg001300

20. Fenwick L., Capelle D., Damm E., Zimmermann S., Williams W.J., Vagle S., Tortell P.D. 2017. Methane and nitrous oxide distributions across the North American Arctic Ocean during summer, 2015. J. of Geophysical Research: Oceans, 122: 390-412. https://doi.org/10.1002/2016JC012493

21. Frederick J.M., Buffett B.A. 2015. Effects of submarine groundwater discharge on the present-day extent of relict submarine permafrost and gas hydrate stability on the Beaufort Sea continental shelf. J. of Geophysical Research: Earth Surface, 120(3): 417-432. https://doi.org/10.1002/2014jf003349

22. Fyke J.G., Weaver A.J. 2006. The effect of potential future climate change on the marine methane hydrate stability zone. J. of Climate, 19(22): 5903-5917. https://doi.org/10.1175/jcli3894.1

23. Gautier D.L., Bird K.J., Charpentier R.R., Grantz A., Houseknecht D.W., Klett T.R., Moore T.E., Pitman J.K., Schenk C.J., Schuenemeyer J.H. et al. 2009. Assessment of undiscovered oil and gas in the Arctic. Science, 324(5931): 1175-1179. https://doi.org/10.1126/science.1169467

24. Geissler W.H., Gebhardt C.A., Gross F., Wollenburg J., Jensen L., Schmidt-Aursch M.C., Krastel S., Elger J., Osti G. 2016. Arctic megaslide at presumed rest. Scientific Reports, 6. https://doi.org/10.1038/srep38529

25. Gentz T., Damm E., Schneider von Deimling J., Mau S., McGinnis D.F., Schlüter M. 2014. A water column study of methane around gas flares located at the West Spitsbergen continental margin. Continental Shelf Research, 72: 107-118. https://doi.org/10.1016/j.csr.2013.07.013

26. Geology and mineral resources of Russia's Shelfs: Atlas. 2004. Ed. by M.N. Alekseev. Moscow: Nauchn. Mir, 108 p. [In Russ] URL: http://www.vsegei.com/ru/public/atlas/

27. Grant A.C., Levy E.M., Lee K., Moffat J.D. 1986. Pisces 4 research submersible finds oil on Baffin Shelf. Geological Survey of Canada, 86-1A: 65-69. https://doi.org/10.4095/120351

28. Greinert J., McGinnis D.F. 2009. Single bubble dissolution model - The graphical user interface SiBu-GUI. Environmental Modelling and Software, 24: 1012-1013. doi:10.1016/j.envsoft.2008.12.011

29. Gresov A.I., Obzhirov A.I., Yatzuk A.V. 2014. Geostructural regularities of the distributions of permafrost in gas- and coal-bearing basins in the north-east of Russia. Kriosfera Zemli, 18(1): 3-11. (In Russ.).

30. Gresov A.I., Obzhirov A.I., Yatsuk A.V., Mazurov A.K., Ruban A.S. 2017. Gas content of bottom sediments and geochemical indicators of oil and gas on the shelf of the East Siberian Sea. Russian J. of Pacific Geology, 11(4): 308-314. https://doi.org/10.1134/s1819714017040030

31. Hanson R.S., Hanson T.E. 1996. Methanotrophic bacteria. Mikrobiology Reviews, 60(2): 439-471.

32. Hinrichs K.U., Boetius A. 2002. The anaerobic oxidation of methane: new insights in microbial ecology and biogeochemistry. In: Wefer G., Billett D., Hebbeln D., Jørgensen B.B., Schlüter M., van Weering T. (eds) Ocean Margin Systems. Berlin, Heidelberg, Springer, 457-477.

33. Hunter S.J., Haywood A.M., Goldobin D.S., Ridgwell A., Rees J.G. 2013. Sensitivity of the global submarine hydrate inventory to scenarious of future climate change. Earth and Planetary Science Letters, 367: 105-115. https://doi.org/10.1016/j.epsl.2013.02.017

34. Ingólfsson Ó., Landvik J.Y. The Svalbard-Barents Sea ice-sheet - Historical, current and future perspectives. 2013. Quaternary Science Reviews, 64: 33-60. doi:10.1016/j.quascirev.2012.11.034

35. IPCC: Climate Change 2013 - The Physical Science Basis - Contribution of Working Group I to the Fifth Assessment Report of the Intergovernmental Panel on Climate Change. 2013. Cambridge: Cambridge Univ. Press, 1535 p. URL: https://www.ipcc.ch/report/ar5/wg1/

36. Jackson R.B. 2000. Belowground processes and global change. Ecological Applications, 10(2): 397-398. https://doi.org/10.2307/2641101

37. Karl D.M., Tilbrook B.D. 1994. Production and transport of methane in oceanic particulate organic matter. Nature, 368(6473): 732-734. https://doi.org/10.1038/368732a0

38. Karl D.M., Beversdorf L., Bjoerkman K.M., Church M.J., Martinez A., DeLong E.F. 2008. Aerobic production of methane in the sea. Nature Geoscience, 1(7): 473-478. https://doi.org/10.1038/ngeo234

39. Kitidis V., Upstill-Goddard R.C., Anderson L.G. 2010. Methane and nitrous oxide in surface water along the North-West Passage, Arctic Ocean. Marine Chemistry, 121(1-4): 80-86. https://doi.org/10.1016/j.marchem.2010.03.006

40. Kittler F., Heimann M., Kolle O., Goeckede M. 2017. Long-term drainage reduces $\mathrm{CO}_{2}$ uptake and $\mathrm{CH}_{4}$ emissions in a Siberian Permafrost Ecosystem. Global Biogeochemical Cycles, 31: 1704-1717. doi:10.1002/2017gb005774

41. Knies J., Damm E., Gutt J., Mann U., Pinturier L. 2004. Near-surface hydrocarbon anomalies in shelf sediments off Spitsbergen: Evidences for past seepages. Geochemistry, Geophysics, Geosystems, 5: Q06003, 14 p. doi:10.1029/2003GC000687

42. Lamarque J.F. 2008. Estimating the potential for methane clathrate instability in the $1 \%-\mathrm{CO}_{2} \mathrm{IPCC}$ AR-4 simulations. Geophysical Research Letters, 35(19): L19806. https://doi.org/10.1029/2008gl035291 
43. Lammers R.B., Shiklomanov A.I., Vörösmarty C.J., Fekete B.M., Peterson B.J. 2001. Assessment of contemporary Arctic river runoff based on observational discharge records. J. of Geophysical Research: Atmospheres, 106: 3321-3334. https://doi.org/10.1029/2000jd900444

44. Li Y., Zhan L., Zhang J., Chen L., Chen J., Zhuang Y. 2017. A significant methane source over the Chukchi Sea shelf and its sources. Continental Shelf Research, 148: 150-158. https://doi.org/10.1016/j.csr.2017.08.019

45. Lorenson T.D., Greinert J., Coffin R.B. 2016. Dissolved methane in the Beaufort Sea and the Arctic Ocean, 1992-2009; sources and atmospheric flux. Limnology and Oceanography, 61: S300-S323. https://doi.org/10.1002/lno.10457

46. Martinez-Cruz K., Leewis M.-C., Herriott I.Ch. 2017. Armando Sepulveda-Jauregui anaerobic oxidation of methane by aerobic methanotrophs in sub-Arctic lake sediments. Science of the Total Environment, 607-608: 23-31. doi:10.1016/j.scitotenv.06.187

47. Matveeva T., Savvichev A.S., Semenova A., Logvina E., Kolesnik A.N., Bosin A.A. 2015. Source, origin, and spatial distribution of shallow sediment methane in the Chukchi Sea. Oceanography, 28(3): 202-217. http://dx.doi.org/10.5670/oceanog.2015.66

48. Mau S., Valentine D., Clark J., Reed J., Camilli R., Washburn L. 2007a. Dissolved methane distributions and air-sea flux in the plume of a massive seep field, Coal Oil Point, California. Geophysical Research Letters, 34: L22603b.

49. Mau S., Rehder G., Arroyo I.G., Gossler J., Suess E. 2007b. Indications of a link between seismotectonics and $\mathrm{CH}_{4}$ release from seeps off Costa Rica. Geochemistry, Geophysics, Geosystems, 8: Q04003. doi:04010.01029/02006GC001326a

50. Mau S., Römer M., Torres M.E., Bussmann I., Pape T., Damm E., Geprägs P., Wintersteller P., Hsu C.-W., Loher M., Bohrmann G. 2017. Widespread methane seepage along the continental margin off Svalbard - from Bjørnøya to Kongsfjorden. Scientific Reports, 7: 42997, 13 p. https://doi.org/10.1038/srep42997

51. McClelland J.W., De'ry S.J., Peterson B.J., Holmes R.M., Wood E.F. 2006. A panarctic evaluation of changes in river discharge during the latter half of the 20th century. Geophysical Research Letters, 33: L06715. doi:10.1029/2006GL025753

52. McGinnis D.F., Greinert J., Artemov Y., Beaubien S. E., Wüest A. 2006. Fate of rising methane bubbles in stratified waters: How much methane reaches the atmosphere? J. of Geophysical Research, 111(C9): C09007. https://doi.org/10.1029/2005jc003183

53. McGuire A.D., Anderson L.G., Christensen T.R., Dallimore S., Guo L., Hayes D.Y., Heimann M., Lorenson T.D., MacDonald R.W., Roulet N. 2009. Sensitivity of the carbon cycle in the Arctic to climate change. Ecological Monographs, 79(4): 523-555. https://doi.org/10.1890/08-2025.1

54. Miller C.M., Dickens G.R., Jakobsson M., Johansson C., Koshurnikov A., O'Regan M., Muschitiello F., Stranne C., Mörth C.M. 2017. Pore water geochemistry along continental slopes north of the East Siberian Sea: inference of low methane concentrations. Biogeosciences, 14: 2929-2953. https://doi.org/10.5194/bg-14-29292017

55. Moore W.S. 1999. The subterranean estuary: a reaction zone of ground water and sea water. Marine Chemistry, 65: 111-125. https://doi.org/10.1016/s0304-4203(99)00014-6

56. Obzhirov A.I. 1979. Geological features of the distribution of natural gases in coal deposits of the Far East. Moscow: Nauka Publ., 71 p. (In Russ.).

57. Obzhirov A.I., Pestrikova N.L., Mishukova G.I., Mishukov V.F., Okulov A.K. 2016. Distribution of methane content and methane fluxes in the Sea of Japan, Sea of Okhotsk, and near-Kuril Pacific. Russian Meteorology and Hydrology, 41(3): 205-212. https://doi.org/10.3103/s1068373916030067

58. Osterkamp T.E. 2001. Sub-sea permafrost. In: Encyclopedia of Ocean Sciences. New York, London: Acad. Press, 5: 2902-2912. https://doi.org/10.1006/rwos.2001.0008

59. Overland J.E., Wang J., Pickart R.S., Wang M. 2014. Recent and future changes in the meteorology of the Pacific Arctic. In: Grebmeier J.M., Maslowski W. (eds) The Pacific Arctic region: ecosystem status and trends in a rapidly changing environment. Dordrecht: Springer, Chapter 2: 17-30.

60. Parmentier F.-J.W., Christensen T.R., Rysgaard S., Bendtsen J., Glud R.N., Else B., van Huissteden J., Sachs T., Vonk J.E., Sejr M.K. 2017. A synthesis of the arctic terrestrial and marine carbon cycles under pressure from a dwindling cryosphere. Ambio, 46: 53-69. https://doi.org/10.1007/s13280-016-0872-8

61. Peterson B.J., Holmes R.M., McClelland J.W., Vörösmarty C.J., Lammers R.B., Shiklomanov A.I., Shiklomanov I.A., Rahmstorf S. 2002. Increasing river discharge to the Arctic Ocean. Science, 298 (5061): 2171-2173. https://doi.org/10.1126/science.1077445

62. Rachold V., Bolshiyanov D.Y., Grigoriev M.N., Hubberten H.-W., Junker R., Kunitsky V.V., Merker F., Overduin P., Schneider W. 2007. Nearshore Arctic subsea permafrost in transition. Eos, Transactions American Geophysical Union, 88: 149-150. https://doi.org/10.1029/2007eo130001

63. Rajan A., Mienert J., Bünz S. 2012. Acoustic evidence for a gas migration and release system in Arctic glaciated continental margins offshore NW-Svalbard. Marine and Petroleum Geology, 32: 36-49. https://doi.org/10.1016/j.marpetgeo.2011.12.008

64. Reagan M.T., Moridis G.J. 2009. Large-scale simulation of methane hydrate dissociation along the West Spitsbergen Margin. Geophysical Research Letters, 36: L23612. doi:10.1029/2009GL041332 
65. Reeburgh W.S. 2007. Oceanic methane biogeochemistry. Chemical Reviews, 107: 486-513. https://doi.org/10.1021/cr050362v

66. Rekant P., Bauch H.A., Schwenk T., Portnov A., Gusev E., Spiess V., Cherkashov G., Kassens H. 2015. Evolution of subsea permafrost landscapes in Arctic Siberia since the late Pleistocene: A synoptic insight from acoustic data of the Laptev Sea. Arktos, 1: 11. https://doi.org/10.1007/s41063-015-0011-y

67. Riedel M., Brent T.A., Taylor G., Taylor A.E., Hong J.K., Jin Y.K., Dallimore S.R. 2017. Evidence for gas hydrate occurrences in the Canadian Arctic Beaufort Sea within permafrost-associated shelf and deep-water marine environments. Marine and Petroleum Geology, 81: 66-78.

https://doi.org/10.1016/j.marpetgeo.2016.12.027

68. Rigby M., Prinn R.G., Fraser P.J., Simmonds P.G., Langenfelds R.L., Huang J., Cunnold D.M., Steele L.P., Krummel P.B., Weiss R.F., O'Doherty S., Salameh P.K., Wang H.J., Harth C.M., Mühle J., Porter L.W. 2008. Renewed growth of atmospheric methane. Geophysical Research Letters, 35(22): L22805, 6 p. https://doi.org/10.1029/2008g1036037

69. Römer M., Wenau S., Mau S., Veloso M., Greinert J., Schlüter M., Bohrmann G. 2017. Assessing marine gas emission activity and contribution to the atmospheric methane inventory: A multidisciplinary approach from the Dutch Dogger Bank seep area (North Sea). Geochemistry, Geophysics, Geosystems, 18(7): 2617-2633. https://doi.org/10.1002/2017gc006995

70. Ruppel C. 2015. Permafrost-associated gas hydrates: Is it really approximately $1 \%$ of the global system? J. of Chemical \& Engineering Data, 60: 429-436. https://doi.org/10.1021/je500770m

71. Ruppel C.D., Kessler J.D. 2017. The interaction of climate change and methane hydrates: climate-hydrates interactions. Reviews of Geophysics, 55(1): 126-168. https://doi.org/10.1002/2016rg000534

72. Ruppel C.D., Herman B.M., Brothers L.L., Hart P.E. 2016. Subsea ice-bearing permafrost on the U.S. Beaufort Margin: 2. Boreholeconstraints. Geochemistry, Geophysics, Geosystems, 17: 4333-4353. doi:10.1002/2016GC006582

73. Sapart C.J., Shakhova N., Semiletov I., Jansen J., Szidat S., Kosmach D., Dudarev O., van der Veen C., Egger M., Sergienko V., Salyuk A., Tumskoy V., Tison J.L., Röckmann T. 2017. The origin of methane in the East Siberian Arctic Shelf unraveled with triple isotope analysis. Biogeosciences, 14: 2283-2292. https://doi.org/10.5194/bg-14-2283-2017

74. Saunois M., Bousquet Ph., Poulter B., Peregon A., Ciais Ph., Canadell J.G., Dlugokencky E.J., Etiope G., Bastviken D., Houweling S. et al. 2016. The global methane budget 2000-2012. Scientific Data, 8: 697-751.

75. Sauter E.J., Muyakshin S.I., Charlou J.-L., Schlüter M., Boetius A., Jerosch K., Damm E., Foucher J.-P., Klages M. 2006. Methane discharge from a deep-sea submarine mud volcano into the upper water column by gas hydrate-coated methane bubbles. Earth and Planetary Science Letters, 243: 354-365. https://doi.org/10.1016/j.eps1.2006.01.041

76. Savvichev A.S., Rusanov I.I., Yusupov S.K., Pimenov N.V., Lein A.Y., Ivanov M.V. 2004. The biogeochemical cycle of methane in the coastal zone and littoral of the Kandalaksha Bay of the White Sea. Microbiology, 73: 457-468. https://doi.org/10.1023/b:mici.0000036992.80509.2a

77. Schuur E.A.G., Bockheim J., Canadell J.G., EuskirchenEu., Field Ch.B., Goryachkin S.V., Hagemann S., Kuhry P., Lafleur P.M., Lee H. et al. 2008. Vulnerability of permafrost carbon to climate change: implications for the global carbon cycle. Bioscience, 58: 701-714. https://doi.org/10.1641/b580807

78. Schuur E.A.G., McGuire A.D., Schädel C., Grosse G., Harden J.W., Hayes D.J., Hugelius G., Koven C.D., Kuhry P., Lawrence D.M., Natali S.M., Olefeldt C., Romanovsky V.E., Schaefer K., Turetsky M.R., Treat C.C., Vonk J.E. 2015. Climate change and the permafrost carbon feedback. Nature, 520(7546): 171-179. https://doi.org/10.1038/nature14338

79. Shakhova N.E., Semiletov I., Salyuk A., Yusupov V., Kosmach D., Gustafsson O. 2010. Extensive methane venting to the atmosphere from sediments of the East Siberian Arctic shelf. Science, 327: 1246-1250. https://doi.org/10.1126/science.1182221

80. Shakhova N., Semiletov I., Leifer I., Sergienko V., Salyuk A., Kosmach D., Chernykh D., Stubbs C., Nicolsky D., Tumskoy V., Gustafsson Ö. 2013. Ebullition and storm-induced methane release from the East Siberian Arctic Shelf. Nature Geoscience, 7: 64-70. https://doi.org/10.1038/ngeo2007

81. Shakhova N., Semiletov I., Gustafsson O., Sergienko V., Lobkovsky L., Dudarev O., Tumskoy T., Grigoriev M., Mazurov A., Salyuk A., Ananiev R., Koshurnikov A., Kosmach D., Charkin A., Dmitrevsky N., Karnaukh V., Gunar A., Meluzov A., Chernykh D. 2017. Current rates and mechanisms of subsea permafrost degradation in the East Siberian Arctic Shelf. Nature Communications, 8: 15872. https://doi.org/10.1038/ncomms 15872

82. Shakirov R.B. 2018. Gasgeochemical fields of the seas of East Asia. Moscow: GEOS, 341 p. +1 insert. ISBN 978-5-89118-783-2. (In Russ.).

83. Shakirov R.B., Sorochinskaya A.V., Obzhirov A.I. 2013. Gasgeochemical anomalies in the sediments of EastSiberian Sea. Vestnik KRAUNTS: Nauki o Zemle = Bull. of Kamchatka Regional Association "EducationalScientific Center”. Earth Sciences, 1(21): 231-243. 
84. Shakirov R.B., Obzhirov A.I., Salomatin A.S., Makarov M.M. 2017. New data on lineament control of modern centers of methane degassing in East Asian seas. Doklady Earth Sciences, 477(1): 1287-1290. https://doi.org/10.1134/s1028334x17110241

85. Shiklomanov I.A., Shiklomanov A.I., Lammers R.B., Vörösmarty C.J., Peterson B.J., Fekete B. 2000. The dynamics of river water inflow to the Arctic Ocean. In: The freshwater budget of the Arctic Ocean: Proceedings of the NATO Advanced Research Workshop, Tallinn, Estonia, 27 April-1 May 1998, p. 281-296. (Nato Science Partnership Subseries: 2).

86. State of the Climate in 2016. In: Blunden J., Arndt D.S. (eds) 2017. Bull. of the American Meteorological Society, 98(8): Si-S277. doi:10.1175/2017BAMSStateoftheClimate.1

87. State of the Climate in 2017. In: Blunden J., Arndt D.S., Hartfield G. (eds) 2018. Bull. of the American Meteorological Society, 99(8): Si-S332. doi:10.1175/2018BAMSStateoftheClimate.1

88. Tarnocai C., Canadell J.G., Schuur E.A.G., Kuhry P., Mazhitova G., Zimov S. 2009. Soil organic carbon pools in the northern circumpolar permafrost region. Global Biogeochemical Cycles, 23(2): GB2023. doi:10.1029/2008GB003327

89. Thornton B.F., Wik M., Crill P.M. 2016. Double counting challenges the accuracy of high-latitude methane inventories. Geophysical Research Letters, 43(24): 12569-12577. https://doi.org/10.1002/2016g1071772

90. Ulomov V.I. 2007. Seismicity. In: The National Atlas of Russia. Vol. 2: Environment (Nature). Ecology. Moscow, p. 56-57. (In Russ.). URL: https://национальныйатлас.pф/cd2/territory.html

91. Vadakkepuliyambatta S., Chand S., Bünz S. 2017. The history and future trends of ocean warming-induced gas hydrate dissociation in the SW Barents Sea. Geophysical Research Letters, 44: 835-844. https://doi.org/10.1002/2016gl071841

92. Vetrov A.A., Lobus N.V., Drozdova A.N., Belyaev N.A., Romankevich E.A. 2018. Methane in water and bottom sediments in three sections in the Kara and Laptev Seas. Oceanology, 58(2): 198-204.

93. Walter K.M., Smith L.C., Chapin F.S. 2007. Methane bubbling from northern lakes: Present and future contributions to the global methane budget. Philosophical Transactions of the Royal Society A: Mathematical, Physical and Engineering, 365: 1657-1676. doi:10.1098/rsta.2007.2036

94. Walvoord M.A., Striegl R.G. 2007. Increased groundwater to stream discharge from permafrost thawing in the Yukon River basin: potential impacts on lateral export of carbon and nitrogen. Geophysical Research Letters, 34: L12402. https://doi.org/10.1029/2007GL030216

95. Westbrook G.K., Thatcher K.E., Rohling E.J., Piotrowski A.M., Pälike H., Osborne A.H., Nisbet E.G., Minshull T.A., Lanoiselle M., James R.H. et al. 2009. Escape of methane gas from the seabed along the West Spitsbergen continental margin. Geophysical Research Letters, 36: L15608. doi:10.1029/2009GL039191

96. Winkelmann D., Stein R. 2007. Triggering of the Hinlopen/Yermak Megaslide in relation to paleoceanography and climate history of the continental margin north of Spitsbergen. Geochemistry, Geophysics, Geosystems, 8: Q06018. doi:10.1029/2006GC001485

97. Zhang M., Qiao F.L., Song Z.Y. 2017. Observation of atmospheric methane in the Arctic Ocean up to $87^{\circ}$ north. Science China: Earth Sciences, 60: 173-179. doi:10.1007/s11430-015-0241-3

98. Zimov S.A., Schuur E.A.G., Chapin F.S. 2006. Permafrost and the global carbon budget. Science, 312(5780): 1612-1613. https://doi.org/10.1126/science.1128908 